\title{
Candida populi, a New Species of Yeast Occurring in Exudates of Populus and Betula Species
}

\author{
ALLEN N. HAGLER, $\dagger$ LEDA C. MENDONÇA-HAGLER, $\dagger$ AND H. J. PHAFF* \\ Department of Food Science and Technology, University of California, Davis, California 95616
}

\begin{abstract}
During a survey of yeasts occurring in exudates of various tree species in the Pacific Northwest of North America, 24 strains of an imperfect yeast were isolated in a wide geographic area, mainly from species of the genus Populus. The isolates were studied by traditional as well as molecular methods, and the results revealed a new species of the genus Candida. The new species is named Candida populi, because its principal habitat is in exudates of Populus species. $C$. populi resembles $C$ andida molischiana but differs from this species in habitat, guanine-plus-cytosine content of the nuclear deoxyribonucleic acid, maximum growth temperature, and ability to assimilate several carbon compounds. The type strain of $C$. populi is strain UCD-FST 68-675B (= CBS 7351 = ATCC 64933).
\end{abstract}

In 1968 Phaff et al. (2) isolated 24 strains of a novel yeast species from sap exudates of various broad-leaved, deciduous trees in the Pacific Northwest of North America. A total of 12 strains were isolated from aspen (Populus tremuloides Michaux), 10 strains were isolated from cottonwoods (Populus trichocarpa Torrey and Gray), and 2 strains were isolated from a species of birch. These isolates were referred to as Torulopsis sp., and they were found in a large area spanning from northern California to central Alaska (Table 1). Sporulation was not observed in individual strains or after mixing in various combinations. All of the isolates exhibited a more or less mucous appearance on agar media, assimilated nitrate as a sole nitrogen source, and demonstrated a fairly uniform pattern of assimilation of carbon compounds. The new species, although mucous, does not fit the definition of the genus Myxozyma (8) because of its fermentative ability and lack of production of amyloid iodophilic material. Therefore, we place it in the genus Candida sensu Yarrow and Meyer (10) and propose to name it Candida populi after the most common genus of host trees.

\section{MATERIALS AND METHODS}

Samples of tree exudates were collected in sterile plastic bags during June and July of 1968 in various locations of Alaska, the Yukon Territory, British Columbia, Washington, Oregon, and northern California (2). The precise locations of the trees with exudates are given in Table 1 . The isolation of pure yeast cultures by streaking onto acidified malt agar ( $\mathrm{pH}$ 3.7) has been described in detail by Phaff et al. (2). Taxonomic responses were determined by methods currently used in yeast identification (7), but additional carbon compounds used in assimilation tests were also employed. These included D-glucosamine, $N$-acetyl-D-glucosamine, hexadecane, methanol, acetone, 2-propanol, and ethyl acetate. The last three compounds were tested by incorporating them at concentrations of $1 \%$ in yeast nitrogen base agar because in liquid yeast nitrogen base media they proved to be inhibitory, even in those cases where good growth was observed on solid medium.

Deoxyribonucleic acid (DNA) extraction and purification were carried out by using the methods described by Price et al. (4), except that purified DNA was concentrated by

\footnotetext{
* Corresponding author.

$\uparrow$ Present address: Instituto de Microbiologia da UFRJ, Cidade Universitaria CCS bloco I, Rio de Janeiro, R. J. CEP 21.944, Brazil.
}

electrophoresis in a concentrator (ISCO, Lincoln, Nebr.) and the reference DNA was labeled with ${ }^{125} \mathrm{I}$ as described by Holzschu et al. (1). The guanine-plus-cytosine $(\mathrm{G}+\mathrm{C})$ contents of the nuclear DNAs were calculated from buoyant density values in cesium chloride gradients established in a Spinco model E analytical ultracentrifuge equipped with photographic optics $(5,6)$ and were based on three separate determinations. DNA from Micrococcus luteus ICPB 2039 (International Collection of Phytopathogenic Bacteria, Department of Bacteriology, University of California, Davis), with a buoyant density of $1.7310 \mathrm{~g} / \mathrm{ml}$, was used as a reference. The buoyant density of the $M$. luteus DNA was derived from a comparison with plasmid-free Escherichia coli K-12 DNA, the buoyant density of which was taken to be $1.7100 \mathrm{~g} / \mathrm{ml}$. Denaturation of DNA, incubation for reassociation, analysis of the renaturation kinetics and reannealing reactions, and quantitation of single- and doublestranded DNAs were carried out by using the protocol of Price et al. (4). Samples were counted with a gamma ray counter ( $90 \%$ efficiency; model 1185; Nuclear-Chicago Corp., Des Plaines, Ill.).

\section{RESULTS}

The fieldwork associated with this study yielded 24 glossy, somewhat mucous yeast isolates (Table 1). These organisms had fermentative ability, assimilated nitrate as a sole nitrogen source, had a fairly uniform pattern of assimilation of carbon compounds, did not form pseudo or true hyphae, and lacked the capacity for ascosporulation. They were originally considered to belong in the genus Torulopsis (9) and were keyed to Torulopsis molischiana, which has since been transferred to the genus Candida by Yarrow and Meyer (10) as Candida molischiana. Although there are some similarities in phenotypic properties between $C$. molischiana and the new isolates, the $\mathrm{G}+\mathrm{C}$ content of the nuclear DNA of $C$. molischiana is nearly $12 \mathrm{~mol} \%$ higher (Table 2), which virtually precludes conspecificity. Nevertheless, a DNA hybridization experiment was designed to compare the new isolates with $C$. molischiana and several Hansenula species with DNA base compositions much closer to that of the new species. Pichia nakazawae was used as a negative control. Our results (Table 2) indicated clearly that there is no significant DNA relatedness between the strains from tree exudates and several phenotypically similar species. We describe the strains from tree exudates as a new species below. 
TABLE 1. Strain numbers, host trees, and localities of the isolates studied

\begin{tabular}{|c|c|c|}
\hline $\begin{array}{l}\text { UCD-FST } \\
\text { strain no. }^{a}\end{array}$ & $\begin{array}{l}\text { Host tree With } \\
\text { exudate }\end{array}$ & Location \\
\hline $68-675 \mathrm{~B}^{\mathrm{T} b}, 68-685$ & Populus tremuloides & Delta Junction, Ala. \\
\hline $68-680$ & Populus trichocarpa & Delta Junction, Ala. \\
\hline $68-728 \mathrm{~A}$ & Populus trichocarpa & Canyon Creek, Yukon Territory, Canada \\
\hline $68-731$ & Populus trichocarpa & Mile 982, Alcan Highway, Yukon Territory, Canada \\
\hline $68-791 B$ & Populus trichocarpa & Mile 734, Alcan Highway, Yukon Territory, Canada \\
\hline $68-763$ & Populus tremuloides & Mile 620, Alcan Highway, Yukon Territory, Canada \\
\hline $68-775 \mathrm{~A}$ & Betula sp. & Liard Hot Springs, British Columbia, Canada \\
\hline $68-781 \mathrm{~B}$ & Populus trichocarpa & Mile 480, Alcan Highway, British Columbia, Canada \\
\hline $68-783 B$ & Populus tremuloides & Mile 456, Alcan Highway, British Columbia, Canada \\
\hline $68-804$ & Betula sp. & Mile 345, Alcan Highway, British Columbia, Canada \\
\hline $68-811 \mathrm{~B}$ & Populus trichocarpa & Mile 298, Alcan Highway, British Columbia, Canada \\
\hline $68-835 \mathrm{~B}, 68-840 \mathrm{~B}$ & Populus trichocarpa & Mile 65, Alcan Highway, British Columbia, Canada \\
\hline $68-845 B, 68-842$ & Populus tremuloides & Mile 55, Alcan Highway, British Columbia, Canada \\
\hline $68-852,68-857$ & Populus tremuloides & Dawson Creek, British Columbia, Canada \\
\hline $68-865^{c}, 68-868$ & Populus tremuloides & Moberly Lake, British Columbia, Canada \\
\hline 68-951D & Populus trichocarpa & Mile 6, South of Nanaimo, Vancouver Island, Canada \\
\hline $68-1020 \mathrm{~B}$ & Populus tremuloides & Diamond Lake, Oreg. \\
\hline $68-1013 \mathrm{~A}$ & Populus trichocarpa & Klamath Agency, Calif. \\
\hline
\end{tabular}

${ }^{a}$ UCD-FST, Culture Collection of the Department of Food Science and Technology, University of California, Davis.

${ }^{b} \mathrm{~T}=$ type strain.

${ }^{c}$ From a pupa in the bark of Populus tremuloides.

Latin diagnosis of Candida populi sp. nov. In extracto malti post dies 3 cellulae singulae, binae, aut in catenis brevis; cellulae sphaericae vel ovoideae $(2.2-4.6 \times 2.9-5.2 \mu \mathrm{m})$. Post unum mensem annulus et sedimentum formantur. Cultura in agaro malti post dies $21\left(25^{\circ} \mathrm{C}\right)$ mucosa, glabra, nitida; cellulae capsulae.

In agaro farinae Zea mays post dies 14 pseudomycelium vel mycelium verum nullum.

Glucosum, cellobiosum (exigue), et trehalosum (exigue) fermentantur. Glucosum, maltosum, cellobiosum, trehalosum, melezitosum (lente), D-xylosum, L-arabinosum (lente), D-arabinosum (lente, exigue), D-ribosum, L-rhamnosum, ethanolum, glycerolum, ribitolum, D-mannitolum, D-glucitolum, methyl- $\alpha$-D-glucosidum (lente, exigue), salicinum (lente), glucono- $\Delta$-lactonum, acidum succinicum, acidum citricum, hexadecanum, et $N$-acetylglucosaminum assimilantur at non D-galactosum, L-sorbosum, saccharosum, lac- tosum, melibiosum, raffinosum, inulinum, amylum solubile, erythritolum, galactitolum, 2- et 5-ketogluconatum, acidum lacticum, meso-inositolum, methanolum, 2-propanolum, acetonum, ethyl acetas, nec D-glucosaminum.

Kalium nitricum et ethylaminum assimilantur.

Ad crescentiam vitaminae externae necessariae sunt.

Augmentum in $30^{\circ} \mathrm{C}$, raro in $37^{\circ} \mathrm{C}$.

$\mathrm{G}+\mathrm{C}$ acidi deoxyribonucleati, 37.4-38.9 mol\% (6 stirpes).

Habitatio in exudati species populi et betuli.

Typus stirps UCD-FS\&T 68-675B (= CBS 7351) ex exudato Populus tremuloides isolata est.

In collectione zymotica Centraalbureau voor Schimmelcultures, Delphi Batavorum, sub. no. CBS 7351 deposita est.

Standard description of the type strain of Candida populi. Candida populi (pop'u. li. L. gen. n. populi, of poplar, the principal host trees of the yeast). In malt extract after 3 days at $25^{\circ} \mathrm{C}$, the cells are short ovoidal to spheroidal, occur

TABLE 2. Nuclear DNA base compositions and reannealing between labeled DNA from $C$. populi UCD-FST 68-775A and DNAs from 10 yeast strains and calf thymus ${ }^{a}$

\begin{tabular}{|c|c|c|c|}
\hline Organism or tissue ${ }^{b}$ & $\begin{array}{c}\mathrm{G}+\mathrm{C} \\
\text { content } \\
(\mathrm{mol} \%)^{c}\end{array}$ & $\begin{array}{c}\text { Actual } \\
\text { binding } \\
(\%)^{d}\end{array}$ & $\begin{array}{l}\text { Relative binding } \\
(\%)^{e}\end{array}$ \\
\hline C. populi UCD-FST 68-775A & $38.4 \pm 0.4$ & $71.2 \pm 1.2$ & $(100)$ \\
\hline C. populi UCD-FST $68-675 \mathrm{~B}^{\mathrm{T}}$ & $38.1 \pm 0.2$ & $69.8 \pm 3.7$ & 97.9 \\
\hline C. populi UCD-FST 68-731 & $38.2 \pm 0.4$ & $67.5 \pm 2.3$ & 94.4 \\
\hline C. populi UCD-FST 68-791B & $38.9 \pm 0.2$ & $71.5 \pm 1.7$ & 100.2 \\
\hline C. populi UCD-FST $68-804$ & $37.4 \pm 0.3$ & $68.1 \pm 3.5$ & 95.5 \\
\hline C. populi UCD-FST $68-1020 \mathrm{~B}$ & $38.3 \pm 0.1$ & $54.2 \pm 1.9$ & 74.2 \\
\hline C. molischiana NRRL Y $-2237^{\mathrm{T}}$ & $50.3 \pm 0.0$ & $5.2 \pm 0.3$ & 0.2 \\
\hline Hansenula holstii UCD-FST $61-13^{\mathrm{T}}$ & $36.5 \pm 0.2$ & $6.4 \pm 0.3$ & 1.8 \\
\hline Hansenula beckii UCD-FST $74-68^{\mathrm{T}}$ & $36.4 \pm 0.2$ & $7.5 \pm 0.7$ & 3.6 \\
\hline Hansenula muscicola NRRL Y-7005 ${ }^{\mathrm{T}}$ & $37.0 \pm 0.3$ & $6.3 \pm 1.0$ & 1.7 \\
\hline Pichia nakazawae NRRL Y-7903 ${ }^{\mathrm{T}}$ & $40.4 \pm 0.2$ & $4.8 \pm 0.6$ & 0 \\
\hline Calf thymus & & $4.8 \pm 0.6$ & 0 \\
\hline
\end{tabular}

a ${ }^{125}$ I-labeled DNA $(0.2 \mu \mathrm{g})$ and unlabeled DNA $(200 \mu \mathrm{g})$ were incubated for $24 \mathrm{~h}$ in $0.5 \mathrm{ml}$ of $280 \mathrm{mM}$ phosphate buffer $(\mathrm{pH} 6.8)$ at $63^{\circ} \mathrm{C}$.

${ }^{b}$ NRRL, Northern Regional Research Laboratory, United States Department of Agriculture, Peoria, Ill.

c Average \pm standard deviation of three or more buoyant density determinations.

${ }^{d}$ Average \pm standard deviation for three samples, corrected for zero-time binding (1.9\%).

$c$ Corrected for self-renaturation of labeled DNA (5.2\%) (4). 
singly, in pairs, or in small clusters of three or four cells, and measure 2.2 to 4.6 by 2.9 to $5.2 \mu \mathrm{m}$. A sediment and a thin ring develop after 1 week.

On malt agar after 2 weeks at $20^{\circ} \mathrm{C}$, streak cultures are low convex to flat, glossy, smooth, greyish, and somewhat mucous.

In Dalmau plate cultures on cornmeal agar after 2 weeks pseudomycelium is absent, or a few spotty, rudimentary tufts develop into the agar.

Fermentation: a full tube of gas develops in about 5 days with glucose; cellobiose and trehalose are fermented weakly (about $50 \%$ gas in 2 weeks).

Assimilation of carbon compounds: glucose, maltose, cellobiose, trehalose, melezitose (latent), D-xylose, L-arabinose (latent), D-arabinose (latent and weak), D-ribose, Lrhamnose, ethanol, glycerol, ribitol, D-mannitol, D-glucitol, methyl- $\alpha$-D-glucoside (latent, weak), salicin (latent), glucono- $\Delta$-lactone, succinic acid, citric acid, hexadecane, and $\mathrm{N}$-acetylglucosamine are assimilated; no growth occurs on D-galactose, L-sorbose, sucrose, lactose, melibiose, raffinose, inulin, soluble starch, i-erythritol, galactitol, 2-ketogluconate, 5-ketogluconate, lactic acid, meso-inositol, methanol, 2-propanol, acetone, ethyl acetate, and D-glucosamine.

Assimilation of nitrogen compounds: potassium nitrate, ammonium sulfate, and ethyl amine positive.

Diazonium Blue $B$ reaction is negative.

Growth in a vitamin-free medium is negative.

Growth in amino acid-free medium is positive.

Growth at $30^{\circ} \mathrm{C}$ is positive; growth at $37^{\circ} \mathrm{C}$ is negative.

Acid formation on chalk agar is weak.

Urease activity is negative.

Gelatin liquefaction is negative.

Casein hydrolysis is negative.

Lipolytic activity is negative.

Production of amyloid compounds is negative.

Growth in Wickerham osmotic medium is negative.

Growth in the presence of $100 \mu \mathrm{g}$ of cycloheximide per $\mathrm{ml}$ is positive.

Ubiquinone type, Q-8.

The $\mathrm{G}+\mathrm{C}$ content of the nuclear DNA is $38.8 \pm 0.1 \mathrm{~mol} \%$ (mean \pm standard deviation).

The habitat is in slime exudates of species of Populus in the Pacific Northwest of North America.

The type strain of $C$. populi, strain UCD-FST 68-675B, was isolated from an exudate of Populus tremuloides (trembling aspen) at Delta Junction, Ala. This strain has been deposited in the collection of the Yeast Division of the Centraalbureau voor Schimmelcultures, Delft, The Netherlands, as strain CBS 7351 and in the American Type Culture Collection, Rockville, Md., as strain ATCC 64933.

\section{DISCUSSION}

C. populi is not the anamorph of Hansenula populi, a species that is sympatric with $C$. populi but occurs only in black cottonwood (Populus trichocarpa) and not in Populus tremuloides (3). H. populi has a nuclear DNA composition that is almost $6 \mathrm{~mol} \% \mathrm{G}+\mathrm{C}$ higher than that of $C$. populi, and moreover there are many differences in physiological properties. C. populi, which appears to occur in a large area of the Pacific Northwest in tree exudates of the genera Populus and Betula, was not found during an extensive survey of yeasts occurring in exudates of numerous species of trees on various Japanese islands (2). A possible reason could be that Populus species do not occur in Japanese forests and $C$. populi may be dependent on some insect vector that utilizes Populus exudates for its nutrition or life cycle. As shown in Table $1, C$. populi is occasionally isolated in mixed forests from birch fluxes, but is relatively rare there. Among the various isolates there were minor variations in the degree of growth on melezitose, $D$-arabinose, methyl- $\alpha$-D-glucoside, and the organic acids. A few of the strains grew weakly to moderately at $37^{\circ} \mathrm{C}$, but most were negative for this characteristic. Strain UCD-FST 68-1020B, which was used in the DNA hybridization experiment (Table 2), was somewhat atypical in that no fermentation of cellobiose and trehalose was observed; also, both the assimilation of melezitose and the assimilation of methyl- $\alpha$-D-glucoside were negative, characteristics which were also observed for strains UCDFST 68-1013A and UCD-FST 68-951D. The somewhat lower homology value for strain UCD-FST 68-1020B (Table 2) might have been due to allopatry and a resulting change in metabolic potential.

\section{ACKNOWLEDGMENTS}

This study was supported by Public Health Service grant GM16370 from the National Institute of General Medical Sciences and by grant BSR-87-02185 from the National Science Foundation to H.J.P. and by fellowships to A.N.H. and L.C.M. from Conselho Nacional de Desenvolvimento Cientifico e Technologico (CNPq), Brazil.

We thank Yuzo Yamada for determining the ubiquinone type of the new species.

\section{LITERATURE CITED}

1. Holzschu, D. L., H. L. Presley, M. Miranda, and H. J. Phaff. 1979. Identification of Candida lusitaniae as an opportunistic yeast in humans. J. Clin. Microbiol. 10:202-205.

2. Phaff, H. J., M. W. Miller, M. Yoneyama, and M. Soneda. 1972. A comparative study of the yeast florae associated with trees on the Japanese Islands and on the west coast of North America, p. 759-774. In G. Terui (ed.), Fermentation technology today. Society of Fermentation Technology, Osaka, Japan.

3. Phaff, H. J., Y. Yamada, J. Tredick, and M. Miranda. 1983. Hansenula populi, a new homothallic species of yeast from exudates of cottonwood trees. Int. J. Syst. Bacteriol. 33: 375-380.

4. Price, C. W., G. B. Fuson, and H. J. Phaff. 1978. Genome comparison in yeast systematics: delimitation of species within the genera Schwanniomyces, Saccharomyces, Debaryomyces, and Pichia. Microbiol. Rev. 42:161-193.

5. Schildkraut, C. L., J. Marmur, and P. Doty. 1962. Determination of the base composition of deoxyribonucleic acid from its buoyant density in CsCl. J. Mol. Biol. 4:430-433.

6. Szybalski, W. 1968 . Use of cesium sulfate for equilibrium density gradient centrifugation. Methods Enzymol. 128:330 360 .

7. van der Walt, J. P. 1970. Criteria and methods used in classification, p. 34-113. In J. Lodder (ed.), The yeasts-a taxonomic study. North-Holland Publishing Co., Amsterdam.

8. van der Walt, J. P., A. C. M. Weijman, and J. A. von Arx. 1981. The anamorphic yeast genus Myxozyma gen. nov. Sydowia Ann. Mycol. 34:191-198.

9. van Uden, N., and M. Vidal-Leiria. 1970. Torulopsis Berlese, p. 1235-1308. In J. Lodder (ed.), The yeasts-a taxonomic study. North-Holland Publishing Co., Amsterdam.

10. Yarrow, D., and S. A. Meyer. 1978. Proposal for amendment of the diagnosis of the genus Candida Berkhout nom. cons. Int. J. Syst. Bacteriol. 28:611-615. 